\title{
In vivo Toxicity Assessment after the Detoxification of Aflatoxin Compounds - Contaminated Wheat and Corn by Ozone Gas
}

\author{
T. T. El-Sisy ${ }^{1}$, Asmaa A. Salem ${ }^{{ }^{*}}$, Nivin S. Nail ${ }^{1}$ and Jehan B. Ali ${ }^{1}$ \\ ${ }^{1}$ Regional Center for Food and Feed, Agriculture Research Center, Egypt.
}

\begin{abstract}
Authors' contributions
This work was carried out in collaboration among all authors. All authors designed the study and wrote the protocol. Author TTES wrote the first draft of the manuscript, performed a part of physical and chemical analysis. Author AAS managed the biochemical parameters analysis and revised the written manuscript. Author NSN managed the histopathological experiment and performed the statistical analysis. Author JBA managed the biological experiment and collected the literature searches. All authors read and approved the final manuscript.
\end{abstract}

Article Information

DOI: 10.9734/ARRB/2019/v34i330151 Editor(s):

(1) Dr. Bechan Sharma, Department of Biochemistry, University of Allahabad, India. Reviewers:

(1) Robinson, Victor K., Rivers State University, Nigeria.

(2) Manoj Kumar Ghosh, Kalinga University, India. Complete Peer review History: http://www.sdiarticle4.com/review-history/54014

Original Research Article

Received 10 November 2019

Accepted 15 January 2020

Published 23 January 2020

\section{ABSTRACT}

Aflatoxins (AFs) are dangerous mycotoxins, which include a great number of lipophilic molecules produced by aerobic microscopic fungi belonging to the genus Aspergillus causes health hazard including death to human and livestock. The objective of this study was to evaluate the effectiveness of ozone gas treatment on the fungal growth and detoxification of AFs - contaminated wheat and corn grains. Ozone concentration treatments $40 \mathrm{mg} / \mathrm{Kg}$ wheat for 1 hour and $80 \mathrm{mg} /$ $\mathrm{Kg}$ corn for 2 hours of exposure time respectively were applied to contaminated samples of wheat and corn grains. It was observed that completely inhibition of Aspergillus growth and consequently the total aflatoxin content was decreased. In vivo, the biosafety assessment for 72 male albino rats fed on diet containing $70 \% \mathrm{wt}$. of ozone treated AFs - contaminated grains were evaluated comparing to control groups. Results indicated that rats fed on AFs contaminated grains have significantly increased the serum enzymes activity of alanine aminotransferase (ALT), aspartate aminotransferase (AST), alkaline phosphatase (ALP), gamma glutamyl transferase (GGT), malondialdehyde (MDA) content as well as the serum levels of creatinine, urea, glucose, total 
cholesterol (TC) and triglycerides (TG). Also, it was observed that a significant decrease in the level of serum total protein (TP), albumin (Alb), reduced glutathione (GSH) and testosterone hormone comparing to control groups. However, the oral administration of ozonized groups ameliorated the biochemical parameters compared to rats fed on contaminated grains. Moreover, histopathological studies of liver, kidney and testis tissues of rats fed on contaminated grains that revealed different lesions and changes in tissues, inversely to that improving effects in tissues of ozonized contaminated grains - fed rats. It was concluded that ozonization treatment were most effective in reduction of mold count and degradation of aflatoxins content for grains during storage.

Keywords: Aspergillus; Aflatoxins; ozone gas; storage; wheat; corn; biochemical parameters.

\section{INTRODUCTION}

Aflatoxins are a sort of mycotoxins mainly produced by certain strains of Aspergillus flavus, which are found in agricultural crops as hazard contaminants. AFs can negatively affect health of livestock and poultry due to contaminated feeds. Additionally, AFs have high stability during cropping, storage, transporting, processing, and handling steps. Consequently, innovative evidence-based technologies are urgently required to minimize AFs exposure [1]. Thousands of mycotoxins exist, but only a few represent significant food safety challenges. The natural fungal flora associated with foods is dominated by three genera Aspergillus, Fusarium, and Penicillium may include commensals as well as pathogens. The chemical structures of mycotoxins produced by these fungi are very diverse, as are the characteristics of the mycotoxicoses they can cause. AFs may contaminate many crops in hot and humid regions of the world. Human aflatoxicoses continue to be an occasional, serious health problem. Half of the maize food samples tested in districts associated with this outbreak had Aflatoxins $B_{1}$ levels $>20 \mathrm{ppb}$. This outbreak had at least a $39 \%$ incidence of death (317 cases with 125 deaths) resulting from acute hepatotoxicity [2,3]. Aflatoxins production was enhanced by nutrient contents of different grains such as soluble sugars, amino acids and zinc [4]. It was illustrated $A_{F} B_{1}$ binds with steroidogenic acute regulatory (StAR) protein thereby affecting the transport of cholesterol into mitochondria resulting in decreased biosynthesis of testosterone levels [5]. Aflatoxin-contaminated diets caused liver and kidney injury. Moreover, the result indicated that most changes in plasma biochemical indices after treated with 0.7 and 1.4 $\mathrm{mg}$ aflatoxin / $\mathrm{kg}$ diet [6]. Consuming diets contaminated with 0.05 and $0.1 \mathrm{mg} \mathrm{AFB}_{1} / \mathrm{kg}$ exhibited restrained growth performance, impaired reproduction and immune function but fed diet contaminated with $0.02 \mathrm{mg} \mathrm{AFB} / \mathrm{kg}$ did not affect reproductive parameters, but slightly influenced relative liver weight [7]. Ozone (triatomic oxygen, $\mathrm{O}_{3}$ ) is a high oxidising agent, safe and green technology which used for microorganisms growth inhibition and insect disinfestation. Ozone gas also could effectively degrade mycotoxins such as aflatoxins, cyclopiazonic acid (CPA), fumonisin $B_{1}$, ochratoxin A (OTA), patulin, secalonic acid D (SAD) and zearalenone (ZEN) [8], and degradation products are generally harmless. For example, ozone would react across the 8,9 double bond of the furan ring of aflatoxin through electrophilic attack, causing the formation of primary ozonides followed by rearrangement into monozonide derivatives such as aldehydes, ketones and organic acids [9,10,11]. The double bond of the furan ring in $\mathrm{AFB}_{1}$ caused its high toxicity, mutagenicity, and carcinogenic [12].

The structures of AFs $\left(B_{1}, B_{2}\right)$ are difuranocoumarins composed from two furans and a coumarin ring (Fig. 1) according to McKenzie, et al. [8].

Ozone has regulatory acceptance by the Food and Drug Administration (USA) [13] and the Environmental Protection Agency's (USA) MSDS defines it as "pure air". The Occupational Safety \& Health Administration in the United States has established safe ozone concentration levels in the work place of $0.1 \mathrm{ppm}$ and for short durations of $0.3 \mathrm{ppm}$. Ozone is approved in the U.S. and is generally recognized as safe (GRAS) [14]. Ozonation is free of chemical residues process, economically applied to all types of foods, more effective in reducing non- and pathogenic microorganisms of food products without having an unfavorable effect on its visual, textural and nutritional quality and in extending its shelf life [15]. The liver cells were damaged and necrotized, moreover the renal glomerular and tubules were more inversely affected by aflatoxin. Using of ozone, either at 20 and 40 $\mathrm{mg} / 30$ minutes of ozone exposure had a reasonable effect on reducing of aflatoxins at levels of $84 \%$ and $100 \%$, respectively and improving in all tissue status [16]. 


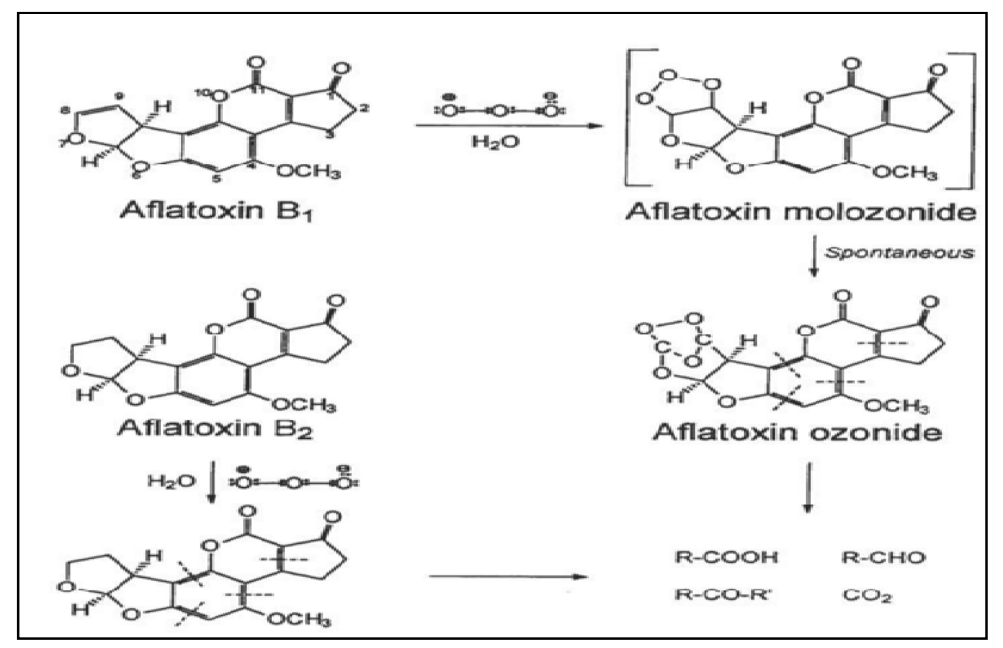

Fig. 1. Mechanism for the addition of ozone to Aflatoxins (B1, B2)

Thus, the objective of the present work was to investigate the effectiveness of ozone as preservatives to control the fungal pollution in the imported wheat and corn grains and to determine the effective dose that can be used as fungicide for wheat grains during storage. As well as biological and histopathological studies for the safety evaluation of ozonized grains on rats.

\section{MATERIALS AND METHODS}

\subsection{Materials}

\subsubsection{Grain samples}

Egyptian wheat grains (Sakha 93) were obtained from El-Gharbia governorate since 2015 and Raw USA imported corn grains (Zea maize) at Alexandria seaport.

\subsubsection{Fungus}

Aspergillus Parasiticus NRRL (3357) for wheat grains and Aspergillus flavus NRRL (20521) for corn grains were obtained from the Agricultural Research Service Culture Collection (Peroia, Illinois, USA), Natural Center for Agricultural Utilization Research(NCAUR).

\subsubsection{Media and chemicals}

The following solutions and media were used for mold enumeration and identification: Peptone water, Rose Bengal chloramphenicol agar (Biolife, Italy). The used chemicals, solvents (of analytical grade) were purchased from Merck (Darmstadt, Germany), unless stated otherwise.

\subsubsection{Aflatoxins}

$\left(B_{1}, B_{2}, G_{1}\right.$ and $\left.G_{2}\right)$ were obtained from Sigma chemical company (St. Louis, MO USA). Precoated TLC plates $(0.2 \mathrm{~mm}$ thick, $20 \times 20 \mathrm{~cm})$ coated with Silica gel/ 60, were obtained from Merck (Darmstadt, Germany).

\subsubsection{Preservatives}

Ozone gas (Concentrations 40 and $80 \mathrm{mg} / \mathrm{Kg}$ for one and two hours of exposure time on ambient air respectively were applied to contaminated samples of wheat and corn grains.), Plastic bottle (Anti chemical reaction resistance) Size, 5.3 liter using Ozone equipment (Air Ozone XT-800 Generator).

\subsection{Methods}

The test of grain quality inspection and Sampling were carried out according to USDA [17]. Infected aflatoxin wheat and corn samples were investigated according to USDA [18]. Measurement of the temperature, moisture, air conduction and humidity in silos under investigation were carried out according to USDA [19].

Twenty $\mathrm{kg}$ of each wheat and corn samples were stored for 90 days at temperature $25^{\circ} \mathrm{C}$ and relative humidity less than $62 \%$ according to methods described in [19]. At the end of storage period, samples were cleaned mechanically to remove dirt, dockage, impurities and other strange grains by the Carter Dockage Tester apparatus according to USDA [20]. Samples were conditioned to $16.5 \%$ moisture level for 
24h, and then milled by Laboratory mill CD1 auto Chopin According to AACC [21].

\subsubsection{Physical properties}

Cleanliness, dockage, shrunken and broken, foreign materials, total damaged kernels and total defects were separated and determined manually (hand picking). Test weight pound per bushel, Test weight $\mathrm{P} / \mathrm{B}=(\mathrm{Kg} /$ Hectoliter $) \div 1.278$ according to USDA [20]. A thousand kernel weights were determined by counting the kernels in a $10 \mathrm{~g}$ wheat sample [21]. Wet and dry gluten and falling number were determined according to A.O.A.C [22].

\subsubsection{Chemical properties}

Moisture (MC), crude protein, ash, crude fiber and fat contents were determined according to $[22,19]$. The nitrogen free extract (N.F.E) was calculated by difference.

\subsubsection{Aflatoxins artificial contamination of grain samples}

One hundred twenty kilograms of wheat and corn samples under study were divided into 6 subsamples and treated as follows:

Twenty $\mathrm{Kg}$ subsample stored as negative control sample containing normal flora of wheat (uncontaminated wheat).

Twenty $\mathrm{Kg}$ subsample artificially inoculated with $10^{3}$ CFU/100 g of toxigenic Aspergillus Parasiticus and stored as positive control sample of wheat (inoculated wheat).

Twenty $\mathrm{Kg}$ subsample artificially inoculated with $10^{3} \mathrm{CFU} / 100 \mathrm{~g}$ toxigenic Aspergillus Parasiticus and stored for 90 day after which mycotoxin content was estimated of wheat (aflatoxin contaminated wheat).

Twenty Kg subsample stored as negative control sample containing normal flora of corn (uncontaminated corn).

Twenty $\mathrm{Kg}$ subsample artificially inoculated with $10^{3}$ CFU/100 g of toxigenic Aspergillus flavus NRRL (3357) and stored as positive control sample of corn (inoculated corn).

Twenty $\mathrm{Kg}$ subsample artificially inoculated with $10^{3} \mathrm{cfu} / 100 \mathrm{~g}$ toxigenic Aspergillus flavus and stored for 90 day after which mycotoxin content was estimated of corn (aflatoxin contaminated corn).
Total fungi count \& fungal identification were carried out using Rose Bengal chloramphenical agar and incubated for $5-7$ days at $25^{\circ} \mathrm{C}$. Fungal identification was performed for isolated fungi $[23,24]$. Determination of Aflatoxins content was done according to the method of A.O.A.C $[25,26]$.

\subsubsection{Ozonization method}

Ozone treatment was carried out for different periods on the fungal count and mycotoxins content of wheat and corn grains before and after storage using ozone equipment (Air Ozone XT800 Generator). Ozone treatment was applied to subsamples of aflatoxin-contaminated wheat and aflatoxin-contaminated corn using ozone equipment (Air Ozone TX-800 Generator) with concentration $40 \mathrm{mg} / \mathrm{Kg} / 1$ hour on ambient air for wheat and $80 \mathrm{mg} / \mathrm{Kg} / 2$ hours on ambient air for corn. During which subsamples were withdrawn each $1 \mathrm{hr}$ to estimate the fungal growth as affected by this treatment. After treatment, all subsamples (No. 1 until 6) were stored for 3 months through which subsamples were withdrawn each weekly to estimate the total fungal count.

\subsection{Biological Evaluation}

\subsubsection{Animals and experimental design}

54 male albino rats (weighed $100 \mathrm{~g}$ ) were obtained from Nile Pharmaceutical co., Cairo, Egypt. Rats were housed under standard laboratory conditions of light/ dark cycle $\left(12 / 12\right.$ h) a temperature of $25 \pm 2^{\circ} \mathrm{C}$ and humidity of $60 \pm 5 \%$. Adaptation of rats was done for one week fed on basal diet with free access to diet and drinking water ad libitum, and then they were divided into the following groups (six animals per group) for eight weeks:

G1 (control group): basal diet; G2 (wheat group): $30 \%$ basal diet $+70 \%$ uncontaminated wheat; G3 (wheat-ozone) $30 \%$ basal diet $+70 \%$ ozone treated wheat; G4 (wheat-aflatoxin) $30 \%$ basal diet $+70 \%$ aflatoxin contaminated wheat; G5 (wheat-ozone group) $30 \%$ basal diet $+70 \%$ ozone treated aflatoxin contaminated wheat; G6 (corn group): $30 \%$ basal diet $+70 \%$ uncontaminated corn; G7 (corn-ozone) 30\% basal diet $+70 \%$ ozone treated corn; G8 (cornaflatoxin) $30 \%$ basal diet $+70 \%$ aflatoxin contaminated corn; G9 (corn-ozone group) 30\% basal diet $+70 \%$ ozone treated aflatoxin contaminated corn. The blood samples were 
collected to obtain sera for the different biochemical parameters analysis.

\subsubsection{Biochemical parameters evaluation}

Determination of serum alanine aminotransferase (ALT), aspartate aminotransferase (AST), alkaline phosphatase (ALP), gamma glutamyl transferase (GGT), total protein (TP), albumin (Alb), creatinine, urea and glucose were measured using VITROS 350 Reference Fluid, Micro Slide Assay (Dry Chemistry system), Ortho-Clinical Diagnostics, Inc., USA. Serum testosterone hormone was determined by VITROS ECiQ Immunodiagnostic System (Micro Wells technology), Ortho-Clinical Diagnostics, Rochester, NY, USA. Serum cholesterol and triglyceride were assessed using Respons 910 clinical chemistry analyzer, DiaSys Diagnostic Systems GmbH, Germany.

\subsubsection{Antioxidant status and oxidative parameters study}

Kits used for the evaluation of MDA, and GSH levels were purchased from Biodiagnostics, Egypt.

\subsubsection{Histopathological studies}

Liver, kidney and testis from each rat of all groups were fixed in $10 \%$ buffered formalin and embedded in paraffin wax. Microtome thickens sections of 3-4 $\mu \mathrm{m}$ were prepared according to the standard procedure and stained with haematoxylin and eosin. Sections were then examined for pathological findings of such as centrilobular necrosis, fatty and lymphocytes infiltration by the light microscope of Leica DM3000 Microsystems, CMS GmbH, Wetzlar, Germany [27].

\subsection{Statistical Analysis}

Each ozonization trial was performed with three replicates for one type of kernels, which a oneway analysis of variance (ANOVA) was used to test differences before and after ozonization and mold count (lowercase letters) by SPSS version 11.5 (SPSS, Chicago, IL, USA) to analyze the data. The level of significance $(P<0.05)$ between treated and non-treated samples was determined with Tukey's HSD range test. A twoway ANOVA was performed to test Comparison of means (uppercase letters) for physical and chemical analysis on all data for two kernel types with and without ozonization or the comparisons between aflatoxins type mold in Tables 1,2 and
3 using Duncan's test [28]. All $p$-values $<0.05$ were considered significant $(n=3)$ all are on a dry weight basis. Computer Duncan test program was employed to biochemical analysis results according to method of Snedecor and Cochran [29] using the least significant difference test (LSD) at the $5 \%$ level of probability and the results was introduced in form of mean $\pm \mathrm{SE}$.

\section{RESULTS AND DISCUSSION}

\subsection{Physical and Chemical Properties of Wheat and Corn Kernels before and after Ozonization}

Chemical composition of wheat and corn used in the study before and after ozonization are given in Table 1, which the moisture content was slightly higher in corn (12.8\%) than wheat $(11.2 \%)$ studied samples. The protein percentage of wheat was higher content $(14.70 \%)$ than corn $(6.90 \%)$. The results showed that highest fat content was in corn $(4.0 \%)$ comparing to wheat $(1.7 \%)$ samples. The Ash percentage was quite close to each other of all grains. Nitrogen free extracts (NFE\%) ranged from $67.42 \%$ (wheat) to $72.30 \%$ (corn). There were slightly significant changes of some properties for all samples after exposure to ozone treatment.

It was observed that slightly increasing the hardness percentage might due to that reduction in MC after exposure to ozone. The ozone oxidation ( $2.5 \mathrm{~g} \mathrm{~m}-3$ ozone concentration for $8 \mathrm{~h}$ ) treatment of stored wheat grains diminished the surface moisture from $12 \%$ to $10.1 \%(\mathrm{w} / \mathrm{w})$ and protein content of the ozone-treated wheat compared to contaminated wheat [30]. Results in Table 2 shows that 1000 kernels wheat ranged from $32.7 \mathrm{~g}$ (wheat) to $314.5 \mathrm{~g}$ (corn). Additionally, it showed that wet, dry gluten, hydration ratio and gluten index for wheat were $(32.7 \%), \quad(9.9 \%), \quad(228.0 \%)$ and $(53.0 \%)$, respectively. All baking quality included (Hagberg falling number, wet and dry gluten content) were significantly improved under ozone exposure. Exposing gluten proteins of wheat kernels to ozone gas for a short period of time (30 min) could ameliorated its physical, chemical properties and rheology properties (SH group, secondary structure) by oxidizing sulfhydryl groups of cysteine to disulfide bonds (polymerization) which improve the protein quality but overexposure to ozone caused partial depolymerization of high to low -molecularweight proteins [31]. 
Ozonation (50 ppm ozone for $30 \mathrm{~d}$ ) of wheat and corn didn't affect on amino acid contents nor the nutritional value of the flour and the starch content [32]. Ozone treatment didn't cause physical and biochemical changes in wheat kernels, Ozone reacts with the chemical constituents present in the grain's outer layer (seed coat) [33]. Prolonged high-concentration ozone exposure led to the degradation of the gluten structure through oxidation, which might explain the lower protein content in treated wheat grain. Fat, fiber, ash and carbohydrate content were found to non-significantly $(P>0.05)$ differ from that in untreated wheat [30]. Ozone exposure (10 to $60 \mathrm{mg} / \mathrm{L}$, from $2-5 \mathrm{~h}$ ) to a wheat grain mass from 2 to $5 \mathrm{~kg}$ can be applied without negatively changing in the quality of the grains which all characteristics of chemical and physical remained similar $(p>0.05)$ to control samples [34]. Falling number in second of corn was higher (710) than in wheat (573) kernels which means the lowest enzyme activity, the results showed slightly increasing after ozonization treatment. Falling number used to determine $\alpha$-amylase activity to evaluate the grain quality. Economic European community recommended that the falling number of flour should exceed than 230 sec [35]. Ozone decrease $\alpha$-amylase activity (treatment for $1.0 \mathrm{~h}$ ) showed positive effects on quality scores by significantly increase in falling number, wet gluten content, flour whiteness, and carboxyl contents of wheat flour and improve the quality [36]. Higher falling number means lower $\alpha$-amylase activity (the falling number rose from 250 in the control to 400 in $0-2.0 \mathrm{sec}$.) in wheat flour samples. Excess a-amylase activity can impair wheat flour quality as enzymatic hydrolysis of starch in food production. Damaged starch is more sensitive to $\alpha$-amylase and its content increased with treatment time, which is more likely to lead to hydrolyzation of the wheat flour by $\alpha$ - amylase to polysaccharides, maltose, glucose, etc. by a-amylase and resulted in a decrease in the viscosity of wheat dough during mixing. Ozone treatment (oxidation) can decrease $\alpha$-amylase activity (increasing of the falling number of wheat flour) as well as, wet gluten content, flour whiteness, falling number and carboxyl contents of wheat flour increased significantly which improved steamed bread properties [36]. Thence, the differences in grain types may be partially attributed due to different growing and environmental conditions accompanied during growing periods [37]. It was found that corn had highest flour yield $(100 \%)$, while wheat had lowest flour yield (55.8\%) respectively. Also, it was concluded that wheat has a good characteristic to bread production according to the result of wheat flour protein content was $13.40 \%$ included wet, dry gluten and water binding which were 28.07, 9.7 and $19 \%$, respectively. Moreover, corn flour had the highest value of falling number and wheat flour had lower values $[38,39,40]$. Protein content not less than $10.2 \%$ Ash content not exceed than $0.9 \%$ and the falling number showed exceed than 200 [41,42]. It was recommended that protein content of durum wheat not less than $10.5 \%$ and ash content not exceed than $1.3 \%$ [41]. There was no significant change in the solubility of oxidized corn starch by dry oxidation process using $\mathrm{O}_{3}$ oxidation could be due to the presence of natural pores in starch granules that allows ozone gas to diffuse into the granule which causing an oxidation of hydroxyl groups ($\mathrm{OH}$ ) of starch by $\mathrm{O}_{3}$ were converted to carbonyl and carboxyl groups in glucose molecule ( $\alpha$ $(1,4)$-glucosidic bonds cleavage) that cause the molecular depolymerization of starch. Increasing carboxyl content (hydrophilic group) can improve starch-swelling potential and affect starch gelatinization properties. Also, Both carboxyl and carbonyl contents varied significantly according to starch type and $\mathrm{O}_{3}$ concentration (carbonyl groups were more than carboxyl groups in the corn starch granules) [43].

Table 1. Proximate analysis of ozonized - contaminated wheat and corn

\begin{tabular}{|c|c|c|c|c|}
\hline \multirow[t]{2}{*}{ Analysis } & \multicolumn{2}{|c|}{ Wheat kernels } & \multicolumn{2}{|c|}{ Corn kernels } \\
\hline & before & after & before & after \\
\hline M.C\% & $11.20^{\mathrm{bB}}$ & $10.50^{\mathrm{CB}}$ & $12.80^{\mathrm{a} A}$ & $12.10^{\mathrm{bA}}$ \\
\hline Protein \% & $14.70^{\mathrm{aA}}$ & $14.68^{\mathrm{aA}}$ & $6.90^{\mathrm{CB}}$ & $6.89^{\mathrm{CB}}$ \\
\hline Fat $\%$ & $1.70^{\mathrm{bc}}$ & $1.72^{\mathrm{bC}}$ & $4.00^{\mathrm{aA}}$ & $4.10^{\mathrm{aA}}$ \\
\hline Ash\% & $1.44^{\mathrm{aA}}$ & $1.45^{\mathrm{aA}}$ & $1.00^{\mathrm{aB}}$ & $1.02^{\mathrm{aB}}$ \\
\hline Fiber $\%$ & $3.54^{\mathrm{aA}}$ & $3.50^{\mathrm{aA}}$ & $3.00^{\mathrm{aB}}$ & $2.90^{\mathrm{aB}}$ \\
\hline NFE\% & $67.42^{\mathrm{cC}}$ & $68.15^{\mathrm{bB}}$ & $72.30^{\mathrm{bA}}$ & $72.99^{\mathrm{aB}}$ \\
\hline Total caloric values $\%$ & $343.78^{\mathrm{cB}}$ & $346.80^{\mathrm{bB}}$ & $352.80^{\mathrm{bA}}$ & $356.42^{\mathrm{aA}}$ \\
\hline
\end{tabular}


Table 2. Physical properties of ozonized - contaminated wheat and corn kernels

\begin{tabular}{|c|c|c|c|c|}
\hline \multirow[t]{2}{*}{ Analyses } & \multicolumn{2}{|c|}{ Wheat kernels } & \multicolumn{2}{|c|}{ Corn kernels } \\
\hline & Before & After & Before & After \\
\hline Weigh g /1000 kernels & $32.7^{\mathrm{cC}}$ & $32.6^{\mathrm{cC}}$ & $314.5^{\mathrm{aA}}$ & $314.4^{\mathrm{a} A}$ \\
\hline Hardness \% & $63.0^{\mathrm{cB}}$ & $63.7^{\mathrm{bB}}$ & $68.0^{\mathrm{aA}}$ & $69.0^{\mathrm{bA}}$ \\
\hline Color & White & White & Yellow & Yellow \\
\hline Wet gluten \% & $32.7^{\mathrm{b}}$ & $33.0^{\mathrm{a}}$ & - & - \\
\hline Dry gluten \% & $9.9^{\mathrm{a}}$ & $10.0^{a}$ & - & - \\
\hline Hydration ratio & $228.0^{\mathrm{b}}$ & $230.0^{a}$ & - & - \\
\hline Gluten index \% & $53.0^{\mathrm{a}}$ & $52.0^{\mathrm{b}}$ & - & - \\
\hline Falling Number in Sec. & $573.0^{\mathrm{cB}}$ & $574.0^{\mathrm{bB}}$ & $710.0^{\mathrm{bA}}$ & $711.0^{\mathrm{aA}}$ \\
\hline
\end{tabular}

\subsection{Effect of Ozone Gas Treatment for Contaminated Corn and Wheat Grains on Aflatoxins Concentration and Mold Count}

The ozone layer in the stratosphere absorbs 80 $100 \%$ UV (A, B, and C) radiation from sunlight to protect the earth from the UV radiation harmful [44]. Table 3 shows six samples of the two different AFs - contaminated grains (wheat and corn), which stored at $25^{\circ} \mathrm{C}$ for 90 days. Environmental moisture content surrounded the samples were modified $18 \%$ and stored, also mold count were 3.5 and $2.4 \log \mathrm{CFU} / \mathrm{g}$ at the beginning for control of natural flora sample of corn and wheat, respectively. While the contaminated samples of corn and wheat were 4.9 and $4.2 \log$ CFU/g independently which infected by $10^{3} \mathrm{CFU} / 100 \mathrm{~g}$ Aspergillus species then the count increased after 90 days at $25^{\circ} \mathrm{C}$ to 6.8 and $5.6 \log \mathrm{CFU} / \mathrm{g}$, respectively. Ozone treatment caused a significant reduction in mold count (less than 1 log CFU/g) for both corn (after $2 \mathrm{hr}$ ) and wheat (after $1 \mathrm{hr}$ ). Total AFs concentration ranged from 30.0 to $43.0 \mathrm{ppb}$ for wheat and corn kernels, which increased to 139.0 and $90.0 \mathrm{ppb}$ in corn and wheat, respectively after contamination. Ozonization reduced significantly the concentration of total AFs less than $0.5 \mathrm{ppb}$ for both corn (after $2 \mathrm{hr}$ ) and wheat (after $1 \mathrm{hr}$ ). Ozone is a strong oxidizer as an electrophilic attack against unsaturated compounds for mycotoxin degradation and antimicrobial activity mechanisms. Ozone may cause bacterial cell leakage (gram-negative bacteria), change in the cell permeability by the lysis of the double bonds (such as $\mathrm{C}=\mathrm{C}, \mathrm{C}=\mathrm{N}$ and $\mathrm{N}=\mathrm{N}$ bonds) of unsaturated lipids in cell wall of bacteria or lipoprotein and lipopolysaccharide layers. $\mathrm{AFG}_{1}$ and $\mathrm{AFB}_{1}$ were the most influenced by $\mathrm{O}_{3}$ process due to the presence of double bonds in their molecules (C8-C9) leading to their breakdown into lower molecular weight products such as organic acids, aldehydes, and ketones $[45,46]$. It was found that ozone-treatment could significantly reduce the level of viable microorganisms on the surface of corn kernels. The mechanisms of ozone to inhibit microbial populations in food occur via the progressive oxidation of vital cellular components [47]. Ozone oxidizes polyunsaturated fatty acids or sulfhydryl group and amino acids of enzymes, peptides, and proteins to shorter molecular fragments. The ozone half-life about (20-50 min), decomposition products no have any hazards for treated samples [1]. Ozone gas (powerful antimicrobial agent) was effective against fungal growth and caused toxins degradation. It showed that $A$. flavus growth was significantly reduced $\left(8.5 \times 10^{1}\right.$ and $5.35 \times 10^{1}$ CFU/g) after $30 \mathrm{~min}$ at $\mathrm{O}_{3}$ concentrations of 40 and $60 \mu \mathrm{mol} / \mathrm{mol}$, respectively. Also, wheat grains had their initial fungi load of $4.9 \times 10^{5} \mathrm{CFU} / \mathrm{g}$ reduced in $96.9 \%$ at gas application of $0.33 \mathrm{mg} / \mathrm{g} / \mathrm{min}$ during $5 \mathrm{~min}$. [33]. The safe limits of AFs for human consumption are $4-30 \mu \mathrm{g} / \mathrm{kg}$.

The EU has set the strictest standards for direct human consumption for products with a concentration of $\mathrm{AFB}_{1}$ and total $\mathrm{AFs}$ have to less than $2 \mu \mathrm{g} / \mathrm{kg}$ and $4 \mu \mathrm{g} / \mathrm{kg}$, respectively $[48,49]$. Remediation of mycotoxins contamination using $60 \mathrm{mg} / \mathrm{L}$ of $\mathrm{O}_{3}$ for $300 \mathrm{~min}$, with $2 \mathrm{~kg}$ samples, it was shown the large fungal count reduction obtained of approximately 3.0 cycles log CFU/g of wheat grains [50]. $A F B_{1}$ and $A F G_{1}$ were more sensitive to ozone exposure than $\mathrm{AFB}_{2}$. After 60 $\mathrm{min}$ of $75 \mathrm{mg} \mathrm{L}^{-1}$ ozone treatment for contaminated corn flour, the contents of $\mathrm{AFB}_{1}$ and total AFs decreased from 53.60 and 68.10 $\mu \mathrm{g} \mathrm{kg}-1$ to 11.38 and $15.46 \mu \mathrm{g} \mathrm{kg}^{-1}$, respectively, 
Table 3. Effect of ozone gas treatment for contaminated corn and wheat grains on aflatoxins concentration and mold count after 90 days storage at $25^{\circ} \mathrm{C}$

\begin{tabular}{|c|c|c|c|c|c|c|c|c|c|c|}
\hline \multirow[t]{3}{*}{ Grains samples } & \multicolumn{2}{|c|}{ Ozone treatment $(\mathrm{mg} / \mathrm{Kg})$} & \multicolumn{5}{|c|}{ Aflatoxins (ppb) conc. After 90 days } & \multicolumn{3}{|c|}{ Mold count log (CFU /g dry wt.) } \\
\hline & \multirow[t]{2}{*}{40} & \multirow[t]{2}{*}{80} & \multirow[t]{2}{*}{$B_{1}$} & \multirow[t]{2}{*}{$\mathrm{B}_{2}$} & \multirow[t]{2}{*}{$\mathbf{G}_{1}$} & \multirow[t]{2}{*}{$\mathbf{G}_{2}$} & \multirow[t]{2}{*}{ Total } & \multicolumn{2}{|c|}{ Storage days } & \multirow[t]{2}{*}{ After $\mathrm{O}_{3}$ treatment } \\
\hline & & & & & & & & 0 & 90 & \\
\hline Control of natural flora of corn & \# & \# & $19.0^{\mathrm{dA}}$ & $10.0^{\mathrm{CB}}$ & $5.0^{\mathrm{bC}}$ & $9.0^{\mathrm{bB}}$ & $43.0^{\mathrm{d}}$ & $3.5^{b}$ & $4.0^{\mathrm{C}}$ & \# \\
\hline Control of contaminated corn & \# & \# & $89.0^{\mathrm{aA}}$ & $25.0^{\mathrm{ab}}$ & $15.0^{\mathrm{ac}}$ & $10.0^{\mathrm{aD}}$ & $139.0^{\mathrm{a}}$ & $4.9^{a}$ & $6.8^{\mathrm{a}}$ & \# \\
\hline Control of natural flora of wheat & \# & \# & $15.0^{\mathrm{dA}}$ & $4.0^{\mathrm{cC}}$ & $6.0^{\mathrm{bC}}$ & $5.0^{\mathrm{cC}}$ & $30.0^{\mathrm{d}}$ & $2.4^{\mathrm{d}}$ & $3.2^{\mathrm{C}}$ & \# \\
\hline Control of contaminated wheat & \# & \# & $70.4^{\mathrm{DA}}$ & $8.6^{\mathrm{bC}}$ & $2.0^{\mathrm{cC}}$ & $9.0^{\mathrm{bC}}$ & $90.0^{\mathrm{b}}$ & $4.2^{\mathrm{C}}$ & $5.6^{\mathrm{b}}$ & \# \\
\hline \multirow[t]{2}{*}{ Ozonized contaminated corn } & \# & $1 \mathrm{hr}$. & $59.0^{\mathrm{cA}}$ & $1.7^{\mathrm{dD}}$ & * & $1.0^{\mathrm{dD}}$ & $61.7^{\mathrm{c}}$ & \# & \# & $3.1^{\mathrm{a}}$ \\
\hline & \# & $2 \mathrm{hr}$. & * & * & * & * & * & & & $<1.0^{\mathrm{b}}$ \\
\hline Ozonized contaminated wheat & $1 \mathrm{hr}$. & \# & * & * & * & * & * & \# & \# & $<1.0^{\mathrm{b}}$ \\
\hline
\end{tabular}

Means with the same letter in the same column are not significantly different at $(P \leq 0.05) ;{ }^{*}=$ Under detection limit (0.5ppb) \# = Not determined; (-) Not detected. Different lowercase (one-way ANOVA) and uppercase (two-way ANOVA) letters denote significant differences between treatments at the 5\% level 
being lower than the maximum of limits $(20 \mu \mathrm{g}$ $\mathrm{kg}^{-1}$ ) [51]. It was indicated that more polar or water-soluble compounds formed from the degradation of ozone to aflatoxin $B_{1}$ [52]. The mechanisms of ozone to inhibit microbial populations in food occur via the progressive oxidation of vital cellular components. Ozone oxidizes polyunsaturated fatty acids or sulfhydryl group and amino acids of enzymes, peptides, and proteins to shorter molecular fragments. In addition, ozone degrades the cell wall envelope of unsaturated lipids resulting in cell disruption and subsequent leakage of cellular contents [53]. Concentration of $\mathrm{AFB}_{1}$ production by $A$. flavus after ozonation for wheat grains at $40 \mathrm{ppm}$ ozone gas were $83.21 \pm 0.005,66.71 \pm 66.71$, and $47.28 \pm$ 0.032 and $42.38 \pm 0.088 \mu \mathrm{g} / 100 \mathrm{ml}$ for $5,10,15$ and 20 min respectively but in media untreated was $185.6 \mu \mathrm{g} / 100 \mathrm{ml}$ [54]. It was concluded that a 0.5 to $\sim 1$ log mold reduction on maize kernels was attained for ozone concentrations between 37 and $1752 \mathrm{ppm}$ [55]. The ozonation process reduced both the total fungal count and the rate of incidence of Aspergillus spp in maize grains exposed to ozone gas at a concentration of 2.14 $\mathrm{mg} \mathrm{L}^{-1}$ for a $50 \mathrm{~h}$ period [56]. The maximum reduction of fungal count was $92.86 \%$, with reduction from $1.87 \mathrm{cfu} / \mathrm{g}$ to $0.13 \mathrm{cfu} / \mathrm{g}$, when the wheat seeds was treated with ozone for $45 \mathrm{~min}$ and dried with air temperature at $50^{\circ} \mathrm{C}$ with improving the physiological quality of wheat seeds [57].

\subsection{Biochemical Parameters Evaluation}

The results of the study indicated that $A F B_{1}$ (produced by Aspergillus Flavus and Aspergillus Parasiticus) induced severe toxicity on serum biochemical parameters tested. The serum ALT, AST, ALP and GGT activities, as well as TP and Alb levels of male albino rats for different groups are shown in Fig. 2. The highest activity of liver enzymes $(p<0.05)$ were indicated in AFscontaminated groups compered to control groups. There were high significance ameliorations in the liver enzymes activity and the concentration of TP and Alb after ozonization treatment groups compered to $\mathrm{AFB}_{1}$ contaminated groups.

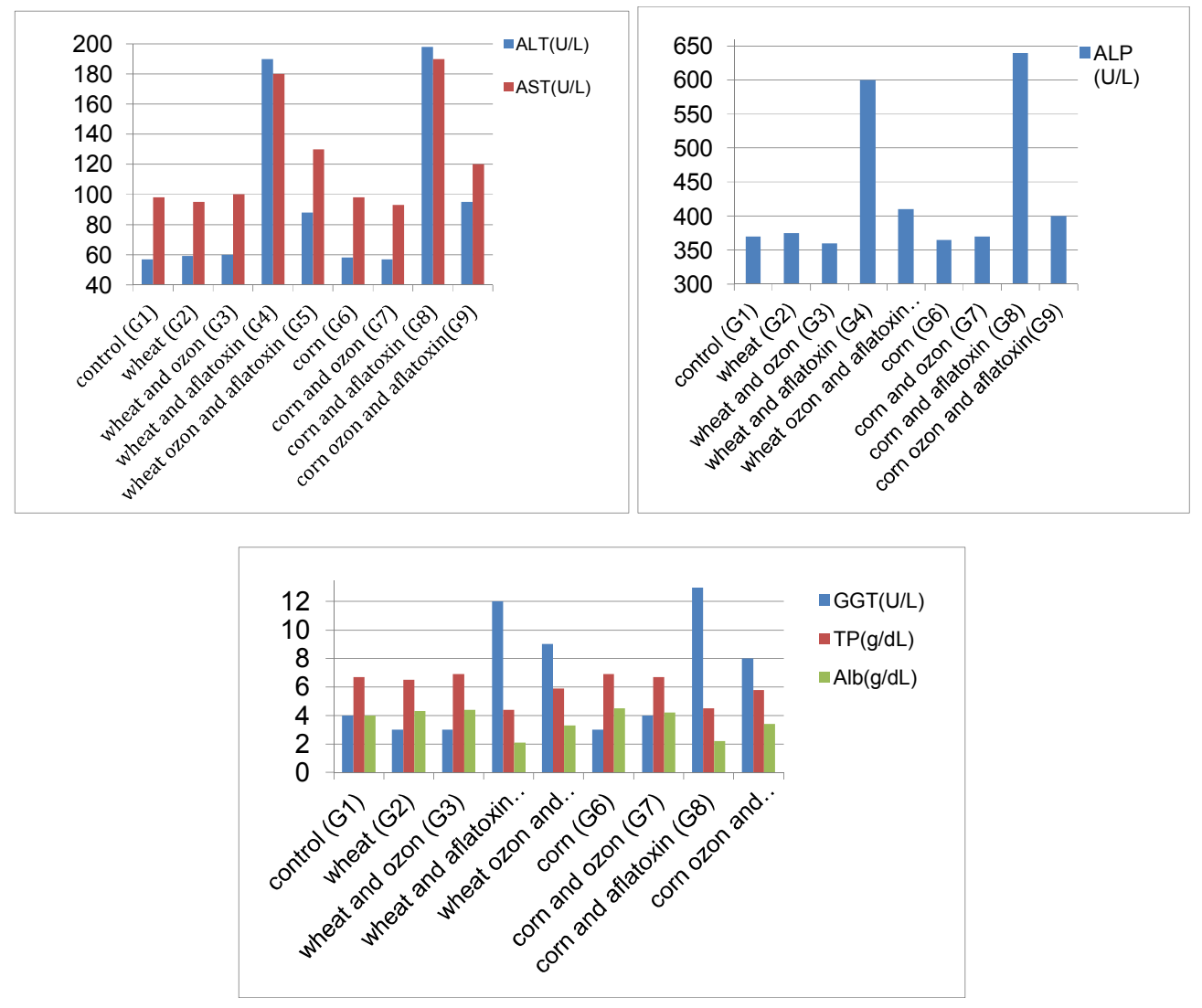

Fig. 2. Serum ALT, AST, ALP and GGT liver enzymes activity - serum TP and ALB levels of AFB $_{1}$ contaminated and ozonized groups 
Animals fed $\mathrm{AFB}_{1}$ - contaminated wheat (2.5 $\mathrm{mg} / \mathrm{kg}$ diet) for 4 weeks showed a significant increase in ALT, AST and ALP compared to the control group. After, ozone gas treatment at 20 and $40 \mathrm{ppm}$ can be used as one of the most effective and safe methods to removal of $A F B_{1}$ without secondary compounds [58]. The AFB ${ }_{1}^{-}$ contaminated corn may lead to significant changes in various physiological characteristics and biochemical indexes in liver (TP, ALB, globulin (GLB) contents, ALT, AST and ALP activities) significantly increased $(p<0.05)$ but ozone treatment of ACC could significantly reduce these changes [59]. As shown in Fig. 3, the serum urea and creatinine levels were high in $\mathrm{AFB}_{1}$ - contaminated groups for wheat and corn compered to control groups. There were significance ameliorations in ozonized contaminated groups in accordance with [60] who reported that high amount of aflatoxin exposure may cause the chronic kidney disease, supporting the neprotoxicitity of aflatoxin in early stage. Therefore, the association between serum creatinine elevation and aflatoxin adduct level showed an impact of aflatoxin to kidney functions.

The effect of ozone treatment for $\mathrm{AFB}_{1}$ contaminated wheat and corn fed rats on the concentrations of serum glucose, TC, TG and testosterone hormone was shown in (Fig. 4). It was illustrated that the $\mathrm{AFB}_{1}$ infection grains fed rats caused increasing significantly in serum glucose, TC and TG but decreasing in testosterone hormone concentrations. The ozonized contaminated groups were significant improved comparing to $\mathrm{AFB}_{1}$ contaminated groups in those mentioned parameters may due to degradation for aflatoxins by $\mathrm{O}_{3}$ and inhibition for adverse effects of toxins. A significant increase was observed in plasma glucose, triglyceride and cholesterol levels of fishes fed aflatoxins may due to disturbance in the carbohydrates' metabolism (energy sources) by decreasing in the activity of G6PD and glycogen stores in the liver against aflatoxin toxicity effects leads to an increase in plasma glucose.

As well as, disturbance of lipoprotein biosynthesis by degradation of fat stores in tissues to deal with aflatoxin toxicity to provide energy and anorexia after damage to the nervous system justifies high triglyceride and cholesterol levels in plasma of fish [6]. It was illustrated $\mathrm{AFB}_{1}$ binds with steroidogenic acute regulatory (StAR) protein thereby affecting the transport of cytosolic cholesterol into mitochondria (to convert into testosterone) resulting in reduction steroidogenesis then decreasing in testicular steroidogenic enzymes and serum testosterone levels in $\mathrm{AFB}_{1}$-treated rats comparing to controls. Human and animals are continuously exposed to aflatoxins $\left(\mathrm{AFB}_{1}\right.$ is a potent endocrine disruptor in vivo) and thus may cause reproductive disorders [5]. Data in Fig. 5 elucidated that MDA level significantly increased in $\mathrm{AFB}_{1}$ - contaminated groups comparing to control groups. Ozonized contaminated groups significantly recovered the MDA elevation ( $p<$ 0.05) compared to contaminated groups. Meanwhile, significant reduction of GSH levels ( $p$ $<0.05)$ in $\mathrm{AFB}_{1}$ - contaminated groups compared to control groups. Ozonized contaminated groups significantly ameliorated that reduction of GSH levels comparing to contaminated groups. The GSH, a key antioxidant, is an important constituent of intracellular protective mechanisms against various noxious stimuli, including oxidative stress as a result of aflatoxin toxicity. GSH depletion in hepatocytes mitochondria indicated to liver injury. The higher GSH levels help to lower $\mathrm{AFB}_{1}$ toxicity by conjugation (detoxification) with the toxin [58].

It was suggested that aflatoxins caused disturbance between antioxidants defense and free radicals attack evidenced by stimulation of lipid peroxidation (MDA) and depleting of GSH [61].

\subsection{Histopathological Examination of Livers, Kidneys and Testis}

\subsubsection{Liver}

Microscopically, liver of rats from G1, G2, G3, G6 and G7 (normal control, wheat control, ozonized normal wheat, corn control and ozonized normal corn) revealed the normal histological structure of hepatic lobule (Figs. $6 \& 7$ ). In contrary, liver of rats from G4 (rats fed contaminated wheat) and G8 (rats fed contaminated corn) revealed focal necrosis of hepatocytes associated with inflammatory cells infiltration and portal infiltration with inflammatory cells (Figs. 8 \& 9), sinusoidal leucocytosis (Fig. 9). However, liver of rats from G 5 and G9 (rats fed ozonized contaminated wheat and corn) revealed no changes except slight Kupffer cells activation (Figs. 10 \& 11) and slight vacuolation of hepatocytes (Fig. 11). Liver of $\mathrm{AFB}_{1}$-contaminant group $(2.5 \mathrm{mg} / \mathrm{kg}$ feed) showed enlarged portal area and dilated thick wall portal vein and accumulation of cellular infiltration and fibrous tissues around proliferated 


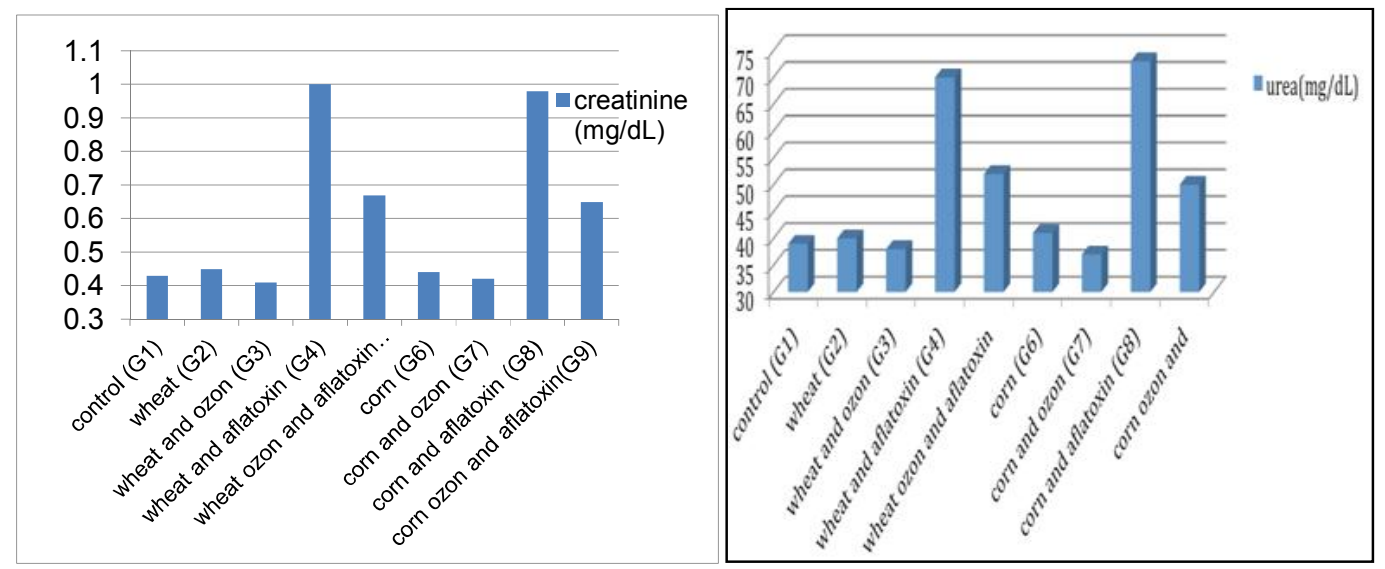

Fig. 3. Serum urea and creatinine levels of $A_{F B} B_{1}^{-}$contaminated and ozonized groups

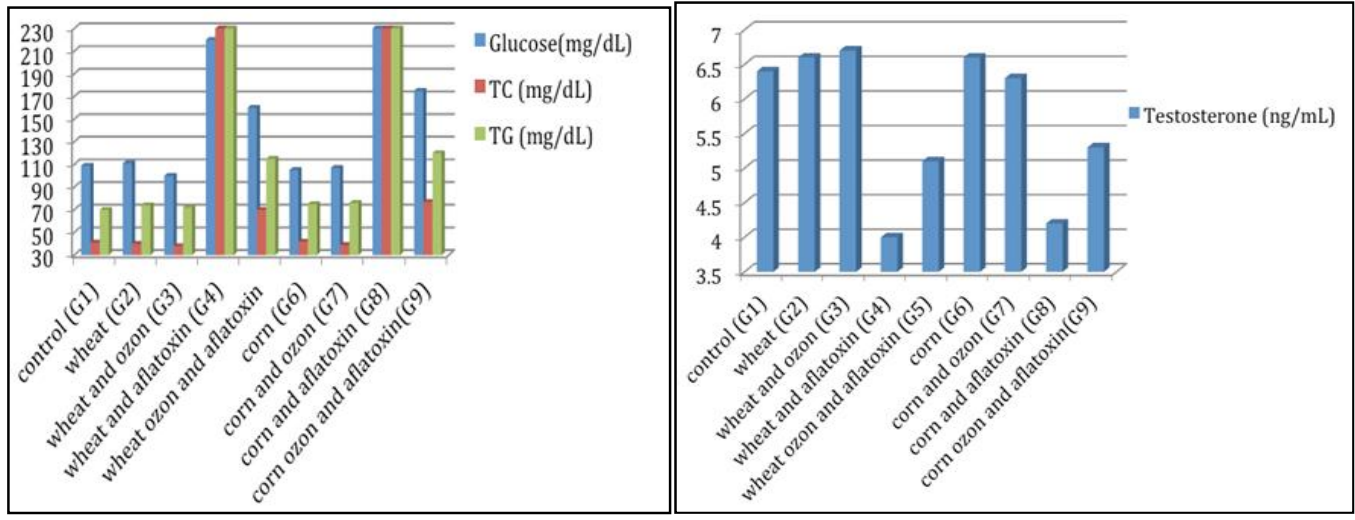

Fig. 4. Serum glucose, TC, TG and testosterone hormone concentrations of $A_{F} B_{1-}$ contaminated and ozonized groups

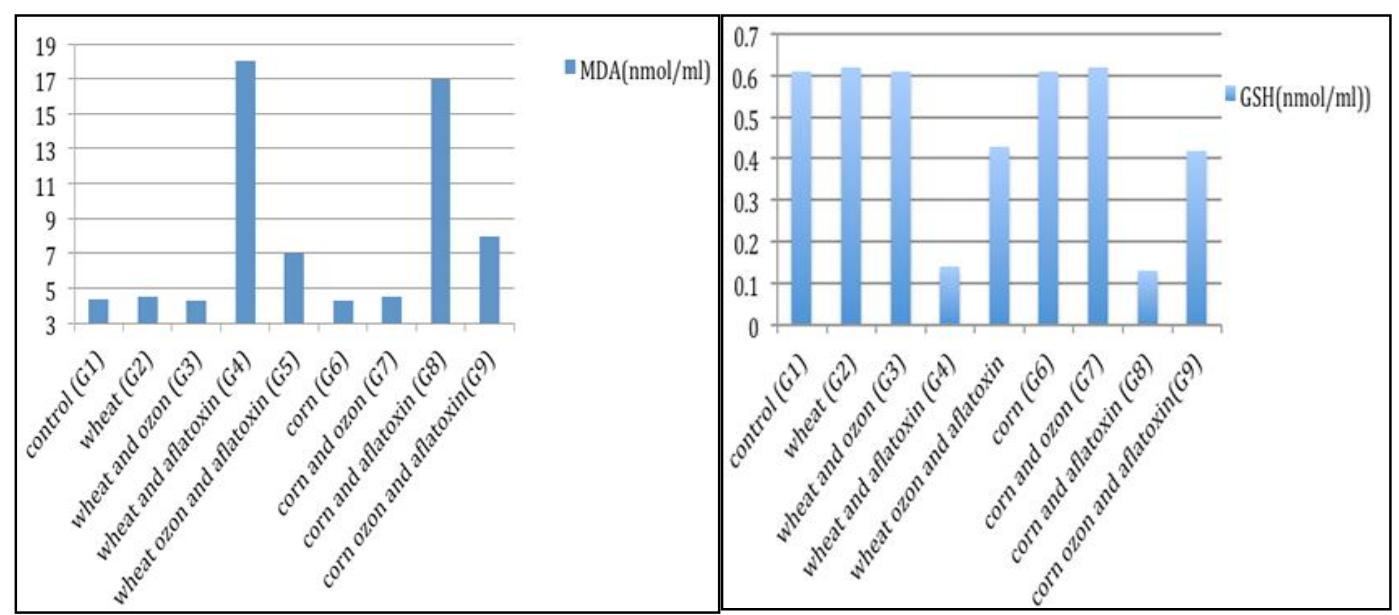

Fig. 5. Serum MDA and GSH levels of $\mathrm{AFB}_{1}$ contaminated and ozonized groups

bile ducts thick, but rats fed $\mathrm{AFB}_{1}$-contaminated diet after ozonation at 20 and / or $40 \mathrm{ppm}$ ozone gas showed the area around the central vein is nearly normal and nearly normal hepatocytes
[58]. It was proved that AFs disrupt liver functions and resulted in releasing of liver enzymes to serum as a consequence of hepatocellular damage (aflatoxicosis). 


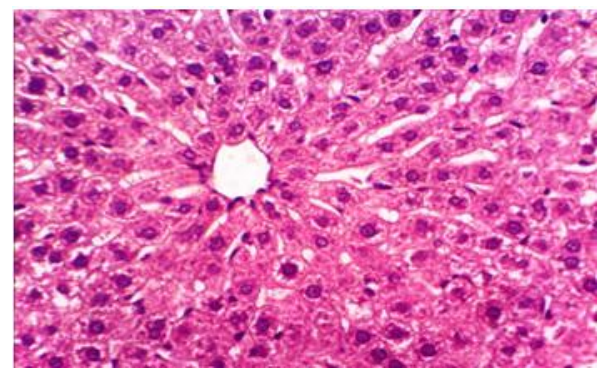

Fig. 6. Liver of rat from $\mathrm{G1}, \mathrm{G} 2$ and $\mathrm{G} 6$ showing the normal histological structure of hepatic lobule (H \& E X 400)

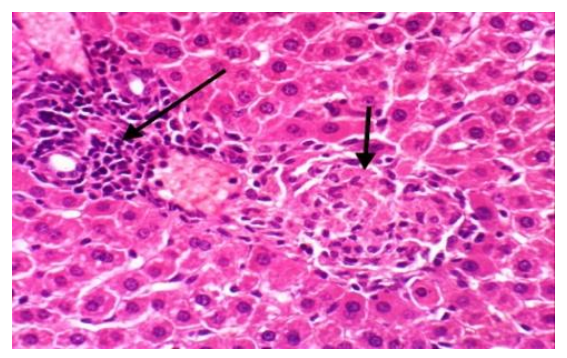

Fig. 8. Liver of rat from G4 showing focal necrosis of hepatocytes associated with inflammatory cells infiltration and portal infiltration with inflammatory cells (H\&EX 400)

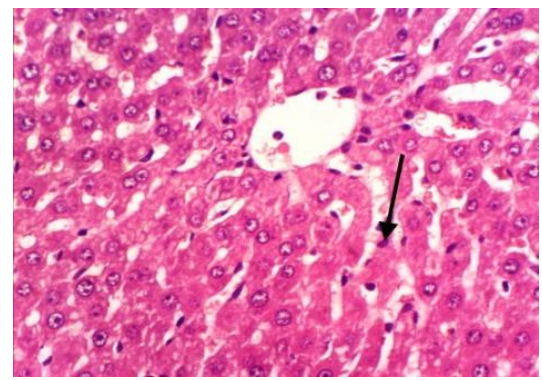

Fig. 10. Liver of rat from $G 5$ showing Kupffer cells activation (H \& E X 400)

The liver is responsible for detoxification of AFs through cytochrome P450 to form reactive intermediate (AFs epoxide formed), which cause cellular injury [61]. The quail exposed to aflatoxin showed liver injuries, characterized by moderate to severe hepatocellular degeneration and necrosis. Moreover, inflammatory cell infiltration, congestion and blood vessels dilatation were found but that all changes decreased after ozonization [62]. Liver tissues from the rats fed $\mathrm{AFB}_{1}$ contaminated corn exhibited dysplasia, obvious fat vacuoles in the hepatic cell

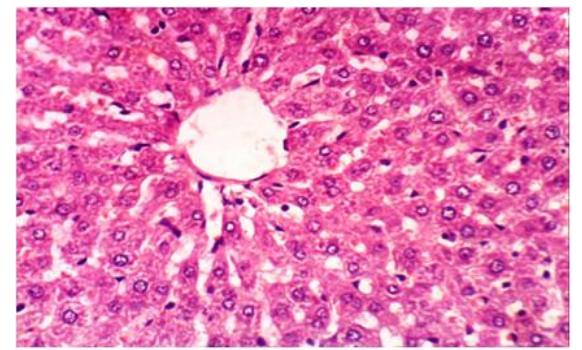

Fig. 7. Liver of rat from $G 3$ and $G 7$ showing the normal histological structure of hepatic lobule (H \& E X 400)

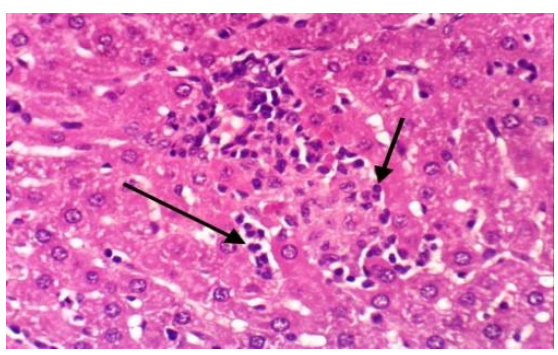

Fig. 9. Liver of rat from $\mathrm{G8}$ showing focal necrosis of hepatocytes associated with inflammatory cells infiltration and sinusoidal leucocytosis (H \& E X 400)

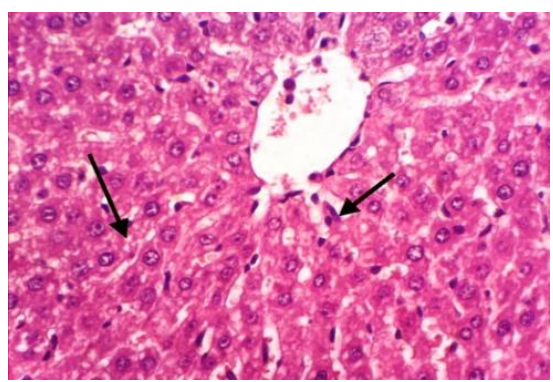

Fig. 11. Liver of rat from G9 showing Kupffer cells activation and slight vacuolation of hepatocytes (H \& E X 400)

cytoplasm, and an obvious nucleolus; as well as, parts with hypochromatosis, hepatic nuclei swollen, cytoplasm loosened, exhibited light staining and apoptosis were observed compered to control and ozonized contamineted corn groups [59].

\subsubsection{Kidney}

Microscopically, kidneys of rats from G1, G2, G3, G6 and G7 (normal control, wheat control, ozonized normal wheat, corn control and 
ozonized normal corn) revealed the normal histological structure of renal parenchyma (Figs. $12 \& 13)$ and no histopathological changes of structure (Fig. 13). On the other hand, Kidney of rats from G4 (rats fed contaminated wheat) showed vacuolation of epithelial lining renal tubules, congestion of glomerular tufts, proteinaceous material in the lumen of renal tubules (Fig. 14). Some examined sections from G8 (rats fed contaminated corn) revealed congestion of renal blood vessel and focal inflammatory cells infiltration (Fig. 15). Meanwhile, kidneys of rats from G5 (rats fed ozonized contaminated wheat) showed apparent normal histopathological structure (Fig. 16). Most examined sections from G9 (rats fed ozonized contaminated corn) revealed slight congestion of glomerular tuft (Fig. 17).

Rats fed AFB1 free diet after ozonation (for wheat) did not show any significant effects however, the ozonized AFB1-contaminated wheat showed a significant improvement in the serum biochemical parameters tested and histological examination in liver and kidney tissues could be due to the degradation of $\mathrm{AFB}_{1}$ by ozonation [58]. In kidney tissue from the CC group, swollen of renal tubular epithelial cells, kidney tubule lumen were smaller and irregular in structure, and cytoplasm loosened and stained light in color with numerous vacuoles compared to control or treatment groups. After ozonization of contaminated corn, no significant pathological changes were found in liver and kidney tissues, indicating that ozone could effectively decrease mice liver and kidney damage from $\mathrm{AFB}_{1}$ and significantly inhibit its toxicity [59]. Kidney tissue of high $A F B_{1}$ group revealed more sever lesions, hypertrophy, cystic dilatation of renal tubules, focal tubular necrosis associated with inflammatory cells infiltration and congestion of glomerular tuft, as well as renal blood vessel [61].

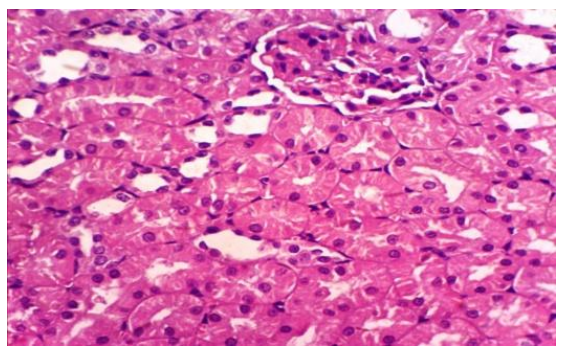

Fig. 12. Kidney of rats from G1, G2 and G6 showing the normal histological structure of renal parenchyma (H \& E X 400)

\subsubsection{Testis}

Microscopically, testes of rats from G1, G2, G3, G6 and G7 (normal control, wheat control, ozonized normal wheat, corn control and ozonized normal corn) showed the normal histological structure of seminiferous tubule with normal spermatogoneal cells and complete spermatogenesis (Figs. 18 and 19).

In contrary, examined sections from G4 (rats fed contaminated wheat) showed degeneration of spermatogoneal cells lining seminiferous tubules with incomplete spermatogenesis and congestion of interstitial blood vessel (Fig. 20) and congestion of interstitial blood vessels (Fig. 21) in G8 (rats fed contaminated corn). However, most examined sections from G5 (rats fed ozonized contaminated wheat) revealed no histopathological changes and (Fig. 22). Meanwhile, few sections from G9 (rats fed ozonized contaminated corn) showed slight degeneration of spermatogoneal cells lining some seminiferous tubules (Fig. 23). Our findings were supported by Eshak, et al. [62] who found that degeneration of the germinal epithelium, rupture in the spermatogenic layer, reduction of sominferous tubules diameter and decrease of spermatogenic cells layer thickness were reported in testis tissues for rats fed $1 \mathrm{mg} / \mathrm{Kg}$ diet $\mathrm{AFB}_{1}$ - contaminated diet but after treatment by ozone for long duration had amelioration in genetic and histopatholgocial changes. The severity of degenerative changes induced by AFs in testes was dose- dependent such as congestion of blood vessels, interstitial edema and degeneration of spermatogoneal cells lining seminiferous tubules [61]. The current study indicated that $\mathrm{AFB}_{1}$ - contaminated diet might lead to significant changes in various biochemical parameters and histopathological tissues in liver, kidney and testes. After ozone treatment of contaminated grains could significantly reduce these changes.

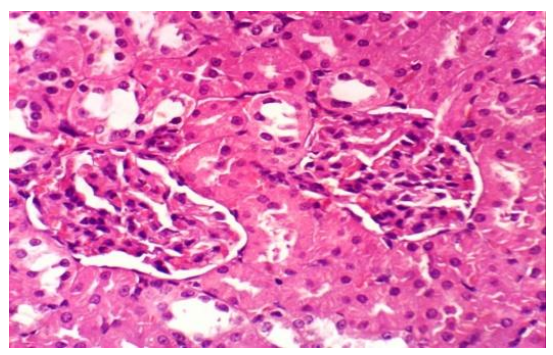

Fig. 13. Kidney of rats from G3 and G7 showing no histopathological changes of renal parenchyma structure (H \& E X 400) 


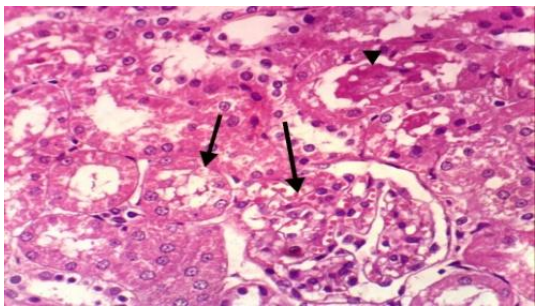

Fig. 14. Kidney of rats from G4 showing vacuolation of epithelial lining renal tubules, congestion of glomerular tufts and proteinaceous material in the lumen of renal tubules (H \& E X 400)

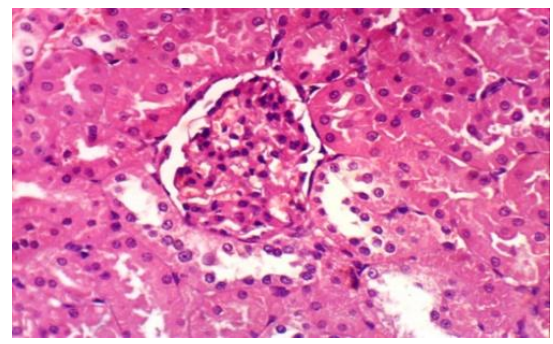

Fig. 16. Kidney of rats from G5 showing apparent normal histopathological structure (H\&EX400)

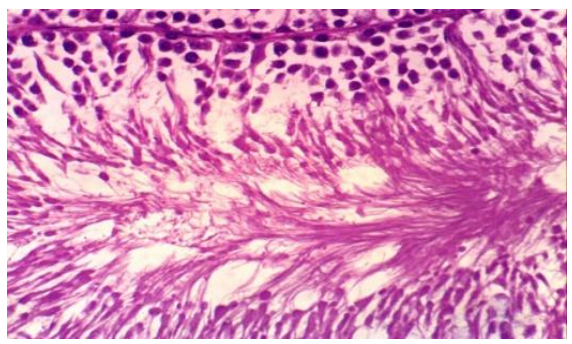

Fig. 18. Testis of rat from $G 1, G 2$ and $G 6$ showing the normal histological structure of seminiferous tubule with normal spermatogoneal cells and complete spermatogenesis (H\&EX400)

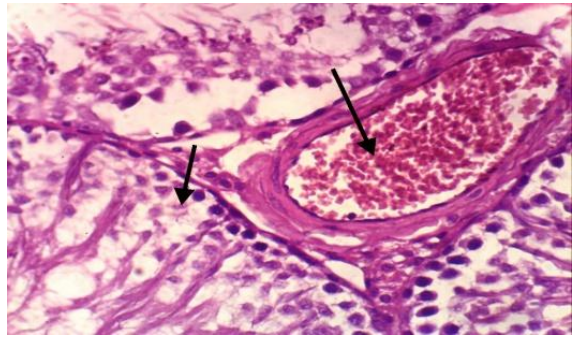

Fig. 20. Testis of rat from $\mathbf{G} 4$ showing degeneration of spermatogoneal cells lining seminiferous tubules with incomplete spermatogenesis and congestion of interstitial blood vessel (H \&E X 400)

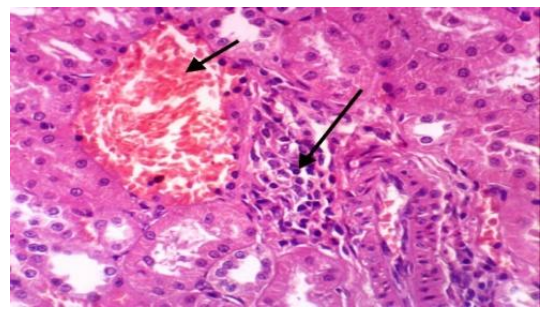

Fig. 15. Kidney of rats from G8 showing congestion of renal blood vessel and focal inflammatory cells infiltration $(H$ \& EX 400)

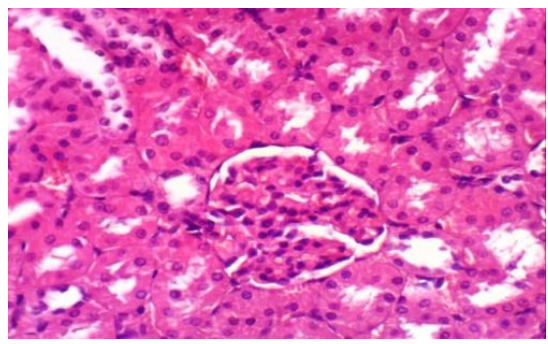

Fig. 17. Kidney of rats from G9 showing slight congestion of glomerular tuft $(H$ \& EX 400)

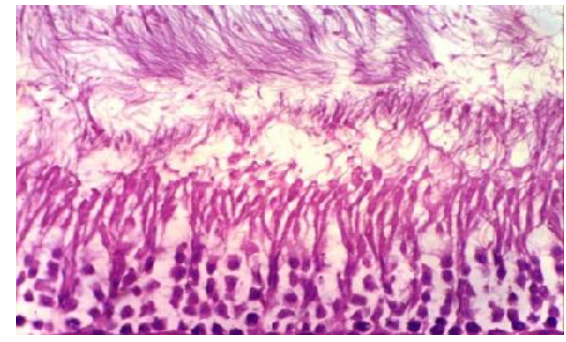

Fig. 19. Testis of rat from G3 and G7 showing no histopathological changes and complete spermatogenesis with sperm production (H\&E X 400)

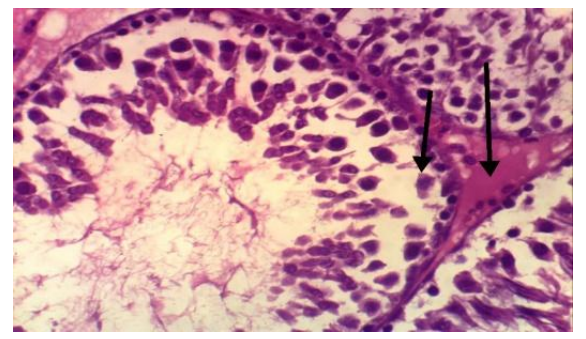

Fig. 21. Testis of rat from $\mathbf{G} 8$ showing degeneration of spermatogoneal cells lining seminiferous tubules with incomplete spermatogenesis and interstitial oedema (H \& E X 400) 


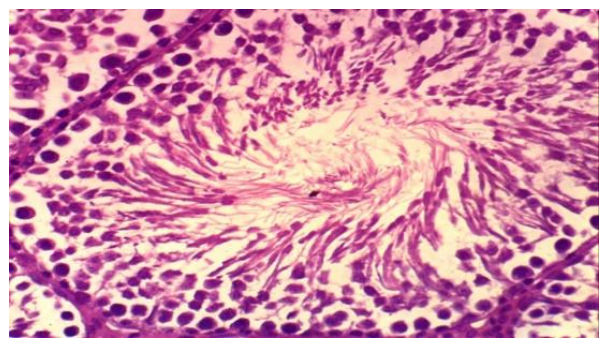

Fig. 22. Testis of rat from G5 showing no histopathological changes (H\&EX400)

\section{CONCLUSION}

It can be concluded that ozone treatment was considered as an oxidizing agent for 1 hour in wheat and 2 hours in corn grains were effective durations to reduce total mold count and bioavailability inhibition of aflatoxins $\left(\mathrm{AFB}_{1}\right)$ without any toxic secondary compounds production. The improvement of biochemical and histopathological indices were shown in ozonized AFB1- contaminated groups. Therefore, it could have significant economic benefits and safe grain storage subsequently decreases health hazards in human being and animal feed.

\section{ETHICAL APPROVAL}

All authors hereby declare that "Principles of laboratory animal care" (NIH publication No. 8523, revised 1985) were followed, as well as specific national laws where applicable. All experiments have been examined and approved by the appropriate ethics committee".

\section{COMPETING INTERESTS}

Authors have declared that no competing interests exist.

\section{REFERENCES}

1. Udomkun PM, Wiredu AN, Nagle M, Müller J, Vanlauwe B, Bandyopadhyay R. Innovative technologies to manage aflatoxins in foods and feeds and the profitability of application. Food Control. 2017;76:127-138.

2. McDonough MX, Campabadal CA, Mason LJ, Maier DE, Denvir A, Woloshuk C. Ozone application in a modified screw conveyor to treat grain for insect pests, fungal contaminants and mycotoxins.

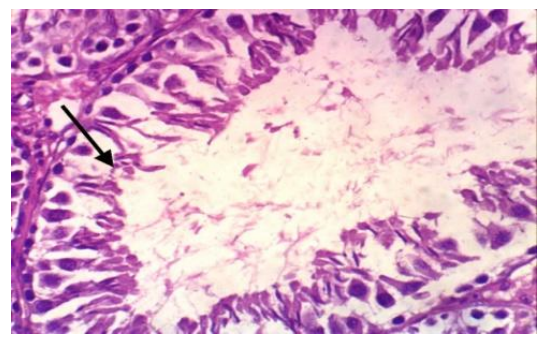

Fig. 23. Testis of rat from G9 showing slight degeneration of spermatogoneal cells lining some seminiferous tubules (H \& E X 400)

Journal of Stored Products Research. 2011;47(3):249-254.

3. Verma VC. Applications and investigations of ozone in cereal grain storage and processing: Benefits and potential drawbacks. Int. J. Curr. Microbiol. App. Sci. 2018;7:5034-5041

4. Liu J, Sun L, Zhang N, Zhang J, Guo J, Li C, Rajput SA, Qi D. Effects of nutrients in substrates of different grains on aflatoxin B1 production by Aspergillus flavus. BioMed Research International. 2016;1:110.

5. Supriya C, Girish BP, Reddy PS. Aflatoxin $\mathrm{B} 1$-induced reproductive toxicity in male rats: Possible mechanism of action. International J. Toxicology. 2014;33(3): 155-161.

6. Vaziriyan M, Banaee M, Nemadoost Haghi $B$, Mohiseni M. Effects of dietary exposure to aflatoxins on some plasma biochemical indices of common carp (Cyprinus carpio). Iranian Journal of Fisheries Sciences. 2018;17(3): 487-502.

7. Sun $Y$, Dong GEG, Liao M, Tao L, Lv J. The effects of low levels of aflatoxin $B_{1}$ on health, growth performance and reproductivity in male rabbits. World Rabbit Sci. 2018;26:123-133.

8. McKenzie KS, Kubena LF, Denvir AJ, Rogers TD, Hitchens GD. Aflatoxicosis in turkey poults is prevented by treatment of naturally contaminated corn with ozone generated by electrolysis. Poult Sci. 1997; 77(8):1094-1102.

9. Proctor AD, Ahmedna M, Kumar JV, Goktepe I. Degradation of aflatoxins in peanut kernels/flour by gaseous ozonation and mild heat treatment. Food Additives and Contaminants. 2004;21:786-793.

10. Dudziak M. Removal of zearalenone from water by means of ozonation and integrated system of ozonation/ 
nanofiltration. Ecol. Chem. Eng. 2012; 19(07):779-785.

11. Souza JVS, Alencar ER, Junqueira AMR, Oliveira GP. Ozone saturation and decomposition kinetics in porous medium containing different hybrids of maize. Revista Brasileira de Engenharia Agrícola e Ambiental. 2018;22(4):286-291.

12. Wang L, Yingpeng L, Xiaohu L, Ren W, Yongfu L, Yanan L, Huili Sh, Zhengxing Ch. Effect of deoxynivalenol detoxification by ozone treatment in wheat Grains. J. Food Control. 2016a;66:137-144.

13. FDA. United States food and drug administration. Rules and Regulations. Federal Register. Part 173-Secondary Direct Food Additives Permitted in Food for Human Consumption (21 CFR Part 173 Authority: 21 U.S.C. $321,342,348)$. 2001; 66(123).

14. FDA. United States Food and Drug Administration. GRAS status of ozone. Federal Register. 1982;47:50209-50210.

15. Brodowskaa AJ, Nowakb A, Smigielskia K. Ozone in the food industry: Principles of ozone treatment, mechanisms of action, and applications: An overview. CRIT. Rev. Food Sci. Nut. 2018;58(13):2176-2201.

16. Shahat MS, Badr AN, Hegaziy Al, Ramzy $S$, Abdel Samie M. Reducing the histopathological and biochemical toxicity of aflatoxins contaminated soybean using ozone treatment. Annual Research \& Review in Biology. 2017;15(3):1-10.

17. USDA U.S. Department of Agriculture, Grain Inspection Handbook I. Grain Inspection, Packers and Stockyards Administration, Federal Grain Inspection Service Probe Sampling, Washington, D.C. 20090-6454; 2013a.

18. USDA. U.S. Department of Agriculture, Grain Inspection Handbook II Grain Inspection, Packers and Stockyards Administration, Federal Grain Inspection Service; 2013b.

19. USDA. U.S. Department of Agriculture, Moisture Handbook Grain Inspection, Packers and Stockyards Administration 1400 Independence Ave., S. W. Washington, D.C. 20250-3600; 2013c.

20. USDA. U.S. Department of Agriculture, Equipment Handbook. Grain Inspection, Packers and Stockyards Administration, S.W. Washington, D.C.; 2016.

21. AACC. American Association of Cereal Chemists, Approved method of the AACC 10th ed., AACC, St Paul, MN. 2000;2.
22. AOAC. Association of official analytical chemists. Official Methods of Analysis. 18th Ed. Published by A.O.A.C. W. Horwitz. North Frederick, U.S.A; 2005.

23. Samson RA, Hoekstra ES, Frisrad JC, Borg OF. Introduction to Food Borne Fungal Handbook, Fourth edition; 1995.

24. British Pharmacopia. Antimicrobial activity. In: Department of Health and Social Security. Her Majesty's Stationery Office, London. 2001;1:123.

25. AOAC. Association of Official Analytical Chemists. Official Methods of Analysis. 15th Ed. Kenneth, H. ed. Published by A.O.A.C. Inc., Virginia, U.S.A.; 1990.

26. AOAC. Association of official analytical chemists. Official Methods of Analysis. 16th Ed. Published by A.O.A.C. Benjamin Franklin station Washington, D.C.; 1995.

27. Banchroft JD, Stevens A, Turner DR. Theory and practice of histological techniques. Fourth (ed). Churchil Livingstone, New York, London, San Francisco, Tokyo. 1996;125.

28. Duncan DB. Multiple ranges and multiple F-Tests. Biometrics.1955;11:1-42.

29. Snedecor GW, Cochran WG. Statistical methods.7th (ed). lowa state University Press, Ames, lowa, USA.; 1980.

30. Mishra G, Palle AA, Srivastava S, Mishra HN. Disinfestation of stored wheat grain infested with Rhyzopertha dominica by ozone treatment: process optimization and impact on grain properties. J. Sci. Food Agric. 2019;99:5008-5018.

31. Obadi $M$, Zhu KX, Peng W, Ammar A, Zhou HM. Effect of ozone gas processing on physical and chemical properties of wheat proteins. Trop. J. Pharm. Res. 2016; 15(10):1319-1326.

32. Wang L, Shao H, Luo X, Wang R, Yongfu L, Yanan L, Luo Y, Chen Z. Effect of ozone treatment on deoxynivalenol and wheat quality. Plos One. 2016b;11(1):3 -13.

33. Savi GD, Piacentini KC, Bittencourt KO, Scussel VM. Ozone treatment efficiency on Fusarium graminearum and deoxynivalenol degradation and its effects on whole wheat grains (Triticum aestivum L.) quality and germination. Journal of Stored Products Research. 2014;59:245-253.

34. Trombete $F$, Minguita A, Porto $Y$, FreitasSilva O, Freitas-Sá D, Freitas S, Carvalho C, Saldanha T, Fraga M. Chemical, technological and sensory properties of wheat grains (Triticum aestivum L.) as affected by gaseous ozonation. Inter- 
national Journal of Food Properties. 2016; 19:2739-2749.

35. Milatovie L, Mondelli G. Pasta technology today. ed. by Chiriotti-Poinerolo (To) -Italy; 1991.

36. Mei J, Liu G, Huang X, Ding W. Effects of ozone treatment on medium hard wheat (Triticum aestivum L.) flour quality and performance in steamed bread making. J. of Food. 2016;14(3):449-456.

37. Randhawa MA, Anjum FM, Butt MS. Physico-chemical and milling properties of new spring wheats grown in Punjab and Sind for the production of pizza. Int. J. Agric. Biol. 2002;4:482-484.

38. El-Sisy TT. Effect of handling, milling process and storage on the quality of wheat and flour in Egypt. Ph.D Food Sci. and Technology Faculty of Environmental Agric. Sci. Suez Canal (Arish) University; 2011.

39. Ehab ASM. Effect of ozonization on the quality storage of yellow corn. M.Sc. of Environmental Sci., Environmental studies and research Institute, Sadat City Univ; 2014.

40. Rabab HM. Using ozone gas in wheat storage and its effect on its grains charactistics and quality attributes. M.Sc. of Environmental Sci., Environmental Studies and Research Institute, Sadat City Univ.; 2014.

41. ES. Egyptian Standard of durum wheat. Egyptian Organization for Standardization and Quality Control, No. 1649. Arab Republic of Egypt; 2004.

42. ES. Egyptian standard of white flour for production of bread. Egyptian Organization for Standardization and Quality Control, No. 1419. Arab Republic of Egypt; 2006.

43. Chan HT, Bhat R, Karim AA. Physicochemical and functional properties of ozone-oxidized starch. J. Agric. Food Chem. 2009;57:5965-5970.

44. Balogh TS, Velasco MVR, Pedriali CA, Kaneko TM, Baby AR. Ultraviolet radiation protection: Current available resources in photoprotection. An Bras Dermatol. 2011; 86(4):732-42.

45. Kim J, Yousef A, Dave S. Application of ozone for enhancing the microbiological safety and quality of foods: A review. Journal of Food Protection. 1999;62(9): 1071-1087.

46. Almeida E, Regina M, Rosa MA, Duran N. Wastewater treatment by oxidation with ozone. Quim Nova. 2004;27(5):818-824.
47. Clurkin R, Keller KM, Keller LAM, González Pereyra ML, Pereyra CM, Dalcero AM, Cavaglieri LR, Lopes CWG. Mycological survey and ochratoxin a natural contamination of swine feedstuffs in Rio de Janeiro State, Brazil. Toxicon. 2009;53(2):283-288.

48. European Commission-EC. Commission Regulation (EC) No. 1126/2007 of 28 September 2007 amending Regulation (EC) No. 1881/2006 setting maximum levels for certain contaminants in foodstuffs as regards Fusarium toxins in maize and maize products. Official Journal of European Union. L 255/14; 2007.

49. European Commission-EC. Commission regulation (EU) no $165 / 2010$ of 26 February 2010, amending regulation (EC) no $1881 / 2006$ setting maximum levels for certain contaminants in foodstuffs as regards aflatoxin. Official Journal of the European Union, 8 -12. L 50.; 2010.

50. Trombete FM, Porto YD, Freitas-Silva O, Pereira RV, Direito GM, Saldanha T, Fraga ME. Journal of Food Processing and Preservation. 2017;41:1-10.

51. Luo X, Wang R, Wang L, Li Y, Wang Y, Chen Z. Detoxification of aflatoxin in corn flour by ozone. J. Sci. Food Agric. 2014; 94:2253-2258.

52. Prudente AD. Evaluation of aflatoxinrelated products from ozonated corn. Doctoral dissertation. Baton Rouge, LA: Louisiana State University; 2008.

53. Das E, Gürakan GC, Bayindirli A. Effect of controlled atmosphere storage, modified atmosphere packaging and gaseous ozone treatment on survival of Salmonella Enteridis on cherry tomatoes. Food Microbiology. 2006;23(5):430-438.

54. El-Desouky TA, Sharoba AMA, El-Desouky Al, El-Mansy HA, Naguib K. Effect of ozone gas on degradation of aflatoxin $B_{1}$ and Aspergillus flavus fungal. $\mathrm{J}$. Environment Analytic Toxicol. 2012;2(2):26.

55. McClurkin JD, Maier DE. Ozone treatment effects on microbial count on maize. In: Carvalho OM, Fields PG, Adler CS, Arthur $\mathrm{FH}$, Athanassiou CG, Campbell JF, Fleurat-Lessard F, Flinn PW, Hodges RJ, Isikber AA, Navarro $S$, Noyes RT, Riudavets J, Sinha KK, Thorpe GR, Timlick $\mathrm{BH}$, Trematerra $\mathrm{P}$, White NDG (eds) Proceedings of the 10th international working conference on stored-product 
protection. Julius-Kuhn-Archiv, Berlin. 2010;548-552.

56. Brito Júnior JG, Antonino Faroni LR, Cecon PR, Nascimento Benevenuto WCA, Benevenuto Júnior $A A$, Heleno FF. Efficacy of ozone in the microbiological disinfection of maize grains. Braz. J. Food Technol. Campinas. 2018;21:1-8.

57. Granella SJ, Christ D, Werncke I, Bechlin TR, Renata S, Coelho M. Effect of drying and ozonation process on naturally contaminated wheat seeds. Journal of Cereal Science. 2018;80:205 -211.

58. El-Desouky TA, Sharoba AMA, El-Desouky Al, El-Mansy HA, Naguib K. Biological and histopathological evaluations of using ozone gas in decontamination of aflatoxinb1 in wheat grains. MOJ Toxicol. 2017;3(4):00057

59. Luo X, Li K, Xing J, Qi L, Yang M, Wang R, Wang L, Li Y, Chen $\mathrm{Z}$. In vivo toxicity assessment of aflatoxin $B_{1}$-contaminated corn after ozone degradation. Food
Additives and Contaminants: Part A. 2018; 35(2):341-350.

60. Mohd Redzwan S, Rosita J, Mohd Sokhini AM, Nurul 'Aqilah AR, Wang J, Kang M, Zuraini A. Detection of serum AFB1-lysine adduct in Malaysia and its association with liver and kidney functions. International Journal of Hygiene and Environmental Health. 2014;217:443-451.

61. Hammoud GM, Abd El-Shafea YM, Salem AA, Nail NS. Effect of grape seeds extract on attenuation of aflatoxins toxicity in rats. International Journal of Green and Herbal Chemistry, Sec. B. 2018;7(2):204223.

62. Eshak MG, Deabes MM, Farrag $A H$, Farag IM, Stino FKR. Effect of ozone-treated aflatoxin contaminated diets on DNA damage, expression of androgen and androgen receptor genes and histopathological changes in Japanese Quail. Global Veterinaria. 2013;11(1):0113.

(c) 2019 El-Sisy et al.; This is an Open Access article distributed under the terms of the Creative Commons Attribution License (http://creativecommons.org/licenses/by/4.0), which permits unrestricted use, distribution, and reproduction in any medium, provided the original work is properly cited.

Peer-review history:

The peer review history for this paper can be accessed here: http://www.sdiarticle4.com/review-history/54014 